\title{
SMART VILLAGE AS A DIRECTION FOR RURAL DEVELOPMENT ${ }^{1}$
}

\author{
Agnieszka Budziewicz-Guzlecka² \\ University of Szczecin
}

\begin{abstract}
Smart villages are an approach to the local development of a village that reflects the contemporary dynamics and direction of development processes as well as the challenges of civilization. It originates not only from observing the processes taking place in the countryside but from "smart" ideas that are widely advertised, for example in the concept of smart development. In Poland, saturation with internet access services is lower in rural areas than in cities. However, the information transmission network is being expanded all the time. Yet, the development of technology alone is not enough to develop smart areas. The concept of smart villages refers to rural areas and communities. This concept must also include regional and local specificities to a large extent.

In smart villages, traditional and new networks and services are strengthened by means of digital technologies, telecommunications, innovation and better use of knowledge, for the benefit of residents and enterprises. The objectives of the presented article are:

- presentation of areas that have an impact on the development of smart villages,

- an indication of the directions of rural development.

The article presents the following research hypothesis - increasing the awareness of rural residents will be conducive to the development of the smart village concept.
\end{abstract}

Key words: smart village, society, ICT.

JEL code: A14, D80.

\section{Introduction}

Currently, the digital economy, which is determined by the intensive development of modern IT technologies, is developing dynamically. The transition to the digital economy is associated with the dissemination of the use of information technology, and above all, advanced data exchange, as well as the development of new forms of communication in society. This development applies to the whole society; however, it proceeds with varying intensity, which is also related to the fact of certain divisions and differences that exist between the city and rural areas.

The peripheral regions do not have the same access to resources and markets and differ in terms of socio-economic conditions and social structures. They are generally characterized by low spatial availability, a negative migration balance and diverse levels of education of residents. They also do not have large potentials for endogenous development (Bilbao-Osorio, Rodríguez-Pose 2004; Naldi et al., 2015). In Poland, saturation with internet access services is lower in rural areas than in cities. However, the information transmission network is being expanded all the time. The concept of smart villages refers to rural areas and communities. This concept must also include regional and local specificities to a large extent. In smart villages, traditional and new networks and services are strengthened by means of digital technologies, telecommunications, innovation and better use of knowledge, for the benefit of residents and enterprises. The objectives of the presented article are:

- presentation of areas that have an influence on the development of smart villages,

- an indication of the directions of rural development.

The article presents the following research hypothesis - increasing the awareness of rural residents will be conducive to the development of the smart village concept. In reference to the assumed goal and adopted hypothesis in the article, the following research question was posed what actions should be taken in the process of striving to achieve the concept of a smart village.

\footnotetext{
${ }^{1}$ The project is financed within the framework of the program of the Minister of Science and Higher Education under the name "Regional Excellence Initiative" in the years 2019 - 2022; project number 001/RID/2018/19; the amount of financing PLN 10,684,000.00

2 agnieszka.budziewicz@wzieu.pl
} 
The research methods used in the work were literature studies and a survey carried out among residents of the Dobra commune.

\section{The essence of smart villages}

The concept of smart villages derives from reflections on smart cities. Initially, the idea of a smart city assumed top-down creation of the city, with particular emphasis on technological solutions as a factor which on the one hand drives the economic development of cities, and on the other hand improves the quality of life in them (Letaifa, 2015). The concept of a smart city indicates the need for widespread use of new technologies to improve the environmental conditions of the city (Fernandes et al., 2011). On the other hand, the key assumption of the smart villages concept (analogically as it is adopted in the smart city concept) is the fact that technological progress, if it is effectively integrated with other rural development initiatives, can create new opportunities to increase revenues, provide services and strengthen social potential, which can significantly improve the quality of rural life (van Gevelt, Holmes, 2015). The above issues point to the differences between smart cities and smart villages. In the case of smart cities, more emphasis is placed on large data sets and the possibilities of transforming the way cities operate thanks to the associated digital technologies. Smart villages are not simply about expanding these principles to dispersed areas. In the case of smart villages, more emphasis is put on local communities that take the future into their own hands - often, but not exclusively, with the help of digital technologies.

Smart villages are an approach to the local development of the village, which reflects the contemporary dynamics and direction of development processes and the challenges of civilization. It originates not only from observing the processes taking place in the villages (Naldi et.al., 2015) but from smart ideas that are widely advertised, for example in the concept of intelligent development.

It should be pointed out that the concept of smart development is one of the key elements of the European economic policy included in the document "Europe 2020", which defines strategic actions aimed at faster economic growth related to the reduction of social inequalities. The problem of implementing the assumptions of the concept of smart development refers to the specificity of the area and resources that it is endowed with.

A smart village is a village that uses advanced technologies to improve the quality of life, maintain the principles of sustainable development, protect the natural environment and achieve the desired effects with the lowest costs incurred in the long run.

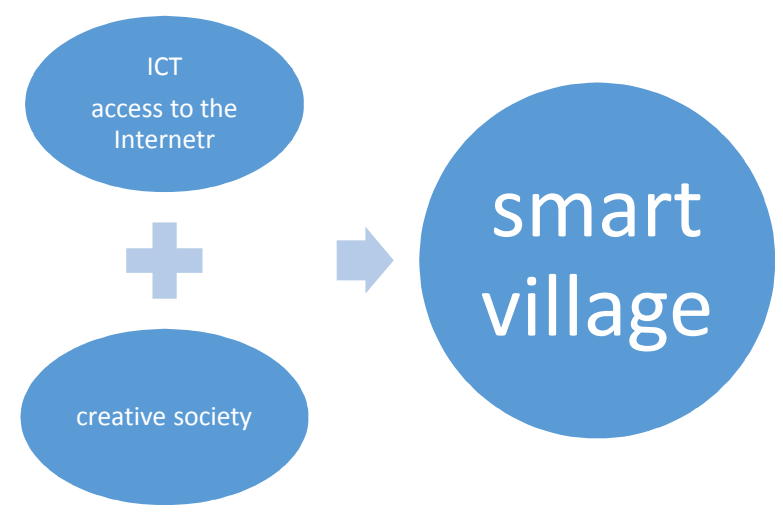

Source: author's study

Fig. 1. The key elements for the development of the smart village concept

As indicated in Figure 1, the key elements for the development of the smart village concept are the use of information transmission techniques and technologies. However, a society that thinks creatively and is open to change, which improves the quality of life is of great importance. Currently, 
more and more attention is paid to the participation of local communities and their ideas in creating a village (Calzada, 2017). It should be noted that creativity and openness to change is expected not only from residents, but also from representatives of these residents, or councillors, commune heads or mayors. Thus, county and municipal authorities should strive to meet the expectations of residents by creating villages that are friendly to life (Bruska, 2012).

Dynamic development is fostered by the use of ICT and creative society. Presented below are the differences in the possession of computers by households in large cities and rural areas with an indication of their use (Table 1 ).

In 2018, nearly $83 \%$ of households had at least one computer in the home. Taking into account different types of households, the possession of computers is quite diverse. In large cities, the percentage of households equipped with computers was larger than in rural areas, as shown in Table 1.

Table 1

Households with computers (in \% of total households of a given group) and people regularly using a computer

\begin{tabular}{|l|c|c|c|c|c|c|}
\hline \multicolumn{7}{|c|}{ Households with computers } \\
\hline \multirow{2}{*}{ specification } & \multicolumn{7}{|c|}{ years } \\
\cline { 2 - 7 } & 2013 & 2014 & 2015 & 2016 & 2017 & 2018 \\
\hline Big cities & 79.1 & 82.0 & 82.9 & 83.2 & 85.7 & 86.6 \\
\hline Rural areas & 71.7 & 73.6 & 75.0 & 77.0 & 78.8 & 81.0 \\
\hline People regularly using a computer & \multicolumn{7}{|c|}{ years } \\
\hline \multirow{2}{*}{ specification } & 2013 & 2014 & 2015 & 2016 & 2017 & 2018 \\
\cline { 2 - 7 } & 71.4 & 74.4 & 75.7 & 79.1 & 80.8 & 79.9 \\
\hline Big cities & 51.4 & 54.8 & 56.0 & 60.5 & 63.2 & 63.5 \\
\hline Rural areas & &
\end{tabular}
Source: author's study based on: Information society in Poland. Results of statistical surveys in the years 20142018, GUS, Warszawa-Szczecin 2018.

The fact that households are equipped with computers does not mean that they are regularly used; however, compared to 2014, the highest increase in this ratio was recorded in rural areas. In rural areas, households were less likely to have broadband access to the global network than households in cities. In 2018, this percentage among households in rural areas amounted to $76.2 \%$, while in large cities - $83.4 \%$. In comparison to 2014, the highest increase in the percentage was recorded in rural areas - by 9.5 percentage points, while in smaller and large cities by 9.1 pp and 5.9 pp respectively, as shown in Table 2.

Table 2

Households with Internet access and broadband access at home (in \% of total households of a given group)

\begin{tabular}{|l|c|c|c|c|c|c|}
\hline \multicolumn{7}{|c|}{ Households with an access to the Internet at home } \\
\hline \multirow{2}{*}{ specification } & \multicolumn{7}{|c|}{ years } \\
\cline { 2 - 7 } & 2013 & 2014 & 2015 & 2016 & 2017 & 2018 \\
\hline Big cities & 76.9 & 79.9 & 81.2 & 82.9 & 85.6 & 87.8 \\
\hline Rural areas & 67.8 & 71.5 & 72.0 & 77.8 & 78.6 & 82.0 \\
\hline Households with a broadband access to the Internet at home \\
\hline \multirow{2}{*}{ Specification } & \multicolumn{7}{|c|}{ years } \\
\cline { 2 - 8 } & 2013 & 2014 & 2015 & 2016 & 2017 & 2018 \\
\hline Bog cities & 75.1 & 77.5 & 77.7 & 79.1 & 81.5 & 83.4 \\
\hline Rural areas & 63.0 & 66.7 & 64.7 & 71.3 & 74.1 & 76.2 \\
\hline
\end{tabular}

Source: author's study based on: Information society in Poland. Results of statistical surveys in the years $2014-$ 2018, GUS, Warszawa-Szczecin 2018. 
The above information indicates that it is important to ensure that households in rural areas have access to the Internet; however, the low number of households using computers is also worrying. This causes that attention should be paid to the training of residents regarding the use of computers and the Internet. Digital technologies can significantly reduce the problems of rural areas that result from remoteness and low population density because they allow instant internet communication and access to electronic services.

\section{Implementation of the smart village concept}

Smart village is a well-functioning future village created by several areas and based on the active action of conscious, independent and decisive citizens. These areas include:

- smart economy - competitiveness,

- smart environment - natural resources,

- smart people - social and human capital,

- smart governance - participation.

The development of the smart economy area should help to establish local connections with other areas. It is connected with competitiveness, which should be achieved through technologically advanced products or services, as well as the introduction of innovations. The introduction of innovations should be strictly defined with specializations so as to build territorial competitive advantages (Rodrigues-Pose, 2004).

M. Wojcik points to smart specialization in rural areas in three contexts (Wojcik 2018, pp. 8-9), i.e.:

- embeddedness - attachment of business entities to the territory is a sign of maturity in economic development; cultural conditions play a big role. Issues such as social neighbourhood and family should not be overlooked;

- connections and closeness (relatedness) - they are very strongly related to the process of transferring knowledge. The economic, technological, but also social link can be considered in relation to the dissemination of information and the knowledge built on it. The role of space in the transfer of knowledge is important, i.e. it takes place mainly at the local level, and even at the neighbourhood level;

- connectivity - the essence of this aspect is the inclusion of networking as an essential feature of economic and social life, especially in the era of rapid development of new technologies. On the one hand, it is the mobility of people in space and the ease of making migration decisions of different social and spatial rank, on the other hand, it is virtual mobility, the ability to act in a parallel reality.

Another area important for the implementation of the smart village concept is the smart environment. It concerns the sustainable use of natural resources, in other words, striving to increase the use of renewable energy sources; for example, street lighting is controlled, pollution is measured, controlled and monitored, buildings are renovated to reduce their energy consumption. This is an area that is difficult to understand and implement, especially for people living in rural areas, who have No knowledge about the harmfulness of obsolete solutions used by them for many years. Attention should be paid to the need to make members of local communities aware of the necessity of implementing changes.

As emphasized by Klodzinski, in the marginalized areas, the preparation of local communities is a very important issue, so that they can by utilising the principles of sustainable development use local resources in a pro-development manner. Further development of education and lifelong learning 
is currently the basic problem and at the same time the basic way to change the human mentality (Klodzinski 2014, p. 109).

The smart people area indicates that the initiators of changes in rural areas should be residents who, thanks to high qualifications and competencies, creativity and cooperation skills with the support of information and communication technologies (ICT) are able to strive to continuously improve the quality of rural life.

On the other hand, in the area of smart governance, social participation in decision making, transparency of action, quality and accessibility of public services play an important role. It is necessary to strengthen civic participation. Participation, generally speaking, can be understood as more or less direct participation of citizens in social, public and political life (Kazmierczak, 2011). Social or community, or horizontal, participation is understood as the participation of members of the local community in collective activities, which include, above all: active presence in the creation and functioning of civic groups and non-profit organizations, as well as permanent or occasional work as a volunteer. One can also indicate individual participation in everyday choices, actions and expectations of the individual in relation to the character and type of society in which he or she wants to function. The civic budget is an example of civic participation, i.e. the residents decide about the purpose of a separate part of the commune's budget in voting. In Poland, the idea of a civic budget came true relatively late - only in 2011, the city of Sopot began its introduction for the first time. In subsequent years, civic budgets were introduced in other cities and in rural areas. However, it is still not a common form of activity of residents in co-deciding about the fate of the places they live in.

For example, in the Dobra commune ${ }^{1}$, in 2018, 23 projects were submitted to the Civic Budget of the Dobra Commune (including 11 investment projects and 12 non-investment projects). The implementation of these projects will start in 2019. The number of registered residents of the Dobra commune amounts to almost 21,000 , while only 1,416 people participated in the vote. The author interviewed 56 residents to obtain information on the reasons for not voting by the residents and the reasons that led in turn to voting. The main reasons for not participating in voting for projects from the citizens' budget were:

- lack of knowledge about the possibility of voting,

- unwillingness to vote, because the respondent does not have the feeling of being a member of a larger community (lack of a sense of belonging),

- unwillingness to vote, resulting from the conviction that this one vote will not change anything,

- lack of conviction that an individual can co-decide on the selection of projects.

The author also interviewed 30 residents who voted in the civic budget. $66 \%$ of them admitted that they were encouraged to vote by information sent on a social network by another person. Other people indicated that their involvement resulted from the willingness to participate in the development of the commune's areas and the conviction of civic responsibility.

As follows from the above studies, the basis should be strengthening social bonds. In this aspect, volunteers from local communities who will initiate the development of these bonds can play an important role. Social bonds will allow for the identification of members of society with the inhabited rural area, which will increase the sense of responsibility for taking part in civic participation. This should be supported by the use of new techniques and technologies by creating, for example,

${ }^{1}$ The Dobra Commune is a rural commune located between the City of Szczecin and the Polish-German border, from the south and north bordering the communes of Police and Kołbaskowo. It consists of 17 localities, forming 12 villages. 
discussion groups of local communities. The basic steps that should be taken to initiate the development of smart villages are presented in Figure 2.

Source: author's study

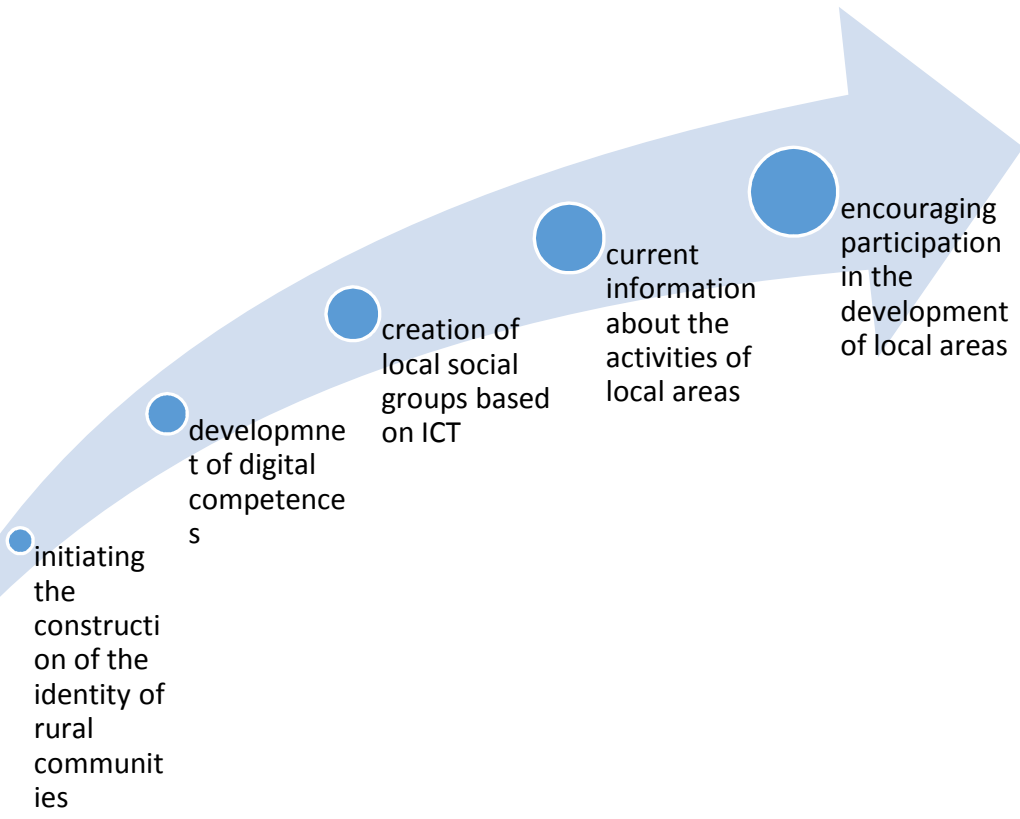

Fig. 2. Steps for implementing the concept of smart villages

The awareness of the possibility of making decisions is very important. This awareness determines the willingness to participate in making decisions for local communities. The local community is responsible for the initial stage of development of smart villages; it jointly develops a strategy based on local resources and aspirations.

It is necessary to support the development of digital infrastructure, competences to use it, but also to assist rural residents with developing solutions that enhance the viability and sustainability of rural areas thanks to social innovation and smart specialization. This will allow for the development leading to a smart village. In the future, a smart village in its development will go beyond the boundaries of the village. Despite the fact that initiatives take place at the local level, smart communities should recognize that the village functions in the setting of a specific landscape, and is also associated with other villages and cities. Therefore, they should activate these connections.

There is not one standard model of a smart village, nor a closed set of tools that they use.

Rural areas oriented towards development towards a smart village, evaluate their resources, apply the best available knowledge and take initiative in shaping the surrounding reality.

\section{Conclusions}

Multifunctional development depends on local conditions, so it will be different in each region. Changes and focus on development should lead to the economic revival of rural areas. The aim of rural development towards a smart village should be taken up by local organizations and residents, creating partner relations, using modern ICT in order to strive for the image of a smart village in the future.

In accordance with the assumed objectives of the presented article, a presentation of the areas affecting the development of smart villages and the directions of development of rural areas was made. The effect of this study was also to prove the hypothesis that in the development of the smart village concept, a key issue is raising the awareness of rural residents. In conclusion, it should be pointed out that this article should be treated as a signalling article, indicating the development of the smart village concepts which will become the starting point for further broader analysis. 


\section{Bibliography}

1. Andersson M., Klaesson J., Larsson J.P., (2016), How Local are Spatial Density Externalities? Neighbourhood effects in agglomeration economies, "Regional Studies", 50: p. 1082-1095.

2. Bruska A., (2012), Logistyka jako komponent smart city, Studia Miejskie, 6, p. 9-19.

3. Calzada I., Cobo C., 2015, Unplugging: Deconstructing the Smart City, Journal of Urban Technology, 22, 1, p. 23-43.

4. European Commission, (2010), Europe 2020: a European Strategy for Smart, Sustainable and Inclusive Growth, European Commission, Brussels.

5. Fernandes O. E., Meeus L., Leal V., Azevedo I., Delarue E., Glachant J.M., 2011, Smart Cities Initiative: How to Foster a Quick Transition towards Local Sustainable Energy Systems. Final Report, Firenze, European University Institute.

6. https://enrd.ec.europa.eu/enrd-thematic-work/smart-and-competitive-rural-areas/smart-villages

7. Information society in Poland. Results of statistical surveys in the years 2014-2018, GUS, WarszawaSzczecin 2018.

8. Kazmierczak T., (2011), Partycypacja publiczna: pojęcie, ramy teoretyczne, [w:] Partycypacja publiczna. O uczestnictwie obywateli w życiu wspólnoty lokalnej, red. A. Olech, Instytut Spraw Publicznych, Warszawa

9. Klodzinski M. (2014). Przedsiębiorczość pozarolnicza na wsi w procesie wielofunkcyjnego rozwoju obszarów wiejskich. Wies i Rolnictwo, 4 (165), p. 97-112.

10. Letaifa S.B., (2015), How to strategize smart cities: Revealing the SMART model, Journal of Business Research, 68, 7, p. 1414-1419.

11. Naldi L., Nilsson P., Westlund H., Wixe F., (2015), What is smart rural development?, Journal of Rural Studies, 40, p. 90-101.

12. Wojcik, M. (2018). Koncepcja inteligentnego rozwoju (smart development)-wyzwanie dla planowania obszarów wiejskich. Acta Universitatis Lodziensis. Folia Geographica Socio-Oeconomica, p. 5-15. 